\title{
Ineffective treatment of PML with pembrolizumab
}

\section{Exhausted memory T-cell subsets as a clue?}

Marc Pawlitzki, MD, * Tilman Schneider-Hohendorf, PhD, * Leoni Rolfes, MD, Sven G. Meuth, MD, PhD, Heinz Wiendl, MD, Nicholas Schwab, PhD,* and Oliver M. Grauer, MD, PhD*

Neurol Neuroimmunol Neuroinflamm 2019;6:e627. doi:10.1212/NXI.0000000000000627

Progressive multifocal leukoencephalopathy (PML) is a rare pathologic CNS condition caused by JC polyomavirus (JCPyV) in immunodeficient patients. Immune checkpoint inhibition was previously reported to potentially facilitate the antiviral response. ${ }^{1}$

Here, we present an ultimately fatal case, where a patient with PML was treated with the antiprogrammed cell death protein (PD)-1 immune checkpoint inhibitor pembrolizumab and compare it with immunologic measurements of samples from a recently published reference case with favorable outcome. ${ }^{2}$

\section{Case report}

A 38-year-old Caucasian man was diagnosed with combined immunoglobulin (Ig) G and IgA deficiency and subsequently treated with IV immunoglobulins at regular intervals. In addition, he developed recurrent severe immune thrombocytopenia, responsive to high dose of methylprednisolone, azathioprine, and at last rituximab.

As Behçet disease had additionally been diagnosed, continued immunotherapy consisted of oral prednisolone $10 \mathrm{mg} / \mathrm{d}$ and recurrent application of IV or subcutaneous immunoglobulins at a 14- or 21-day interval.

In 2018, the patient developed progressive hemianopsia and left-sided hemiparesis. Multiple fluid-attenuated inversion recovery hyperintense lesions in cerebral white matter could be detected on MRI (figure e-1A, links.lww.com/NXI/A153). PCR amplification of JCPyV DNA revealed a very high copy number $(2,561,955$ copies $/ \mathrm{mL})$ in the CSF. Cellular immune status showed complete B-cell depletion $(0$ cell $/ \mu \mathrm{L})$ and low T-cell counts, especially in $\mathrm{CD} 4^{+-}$ lymphocytes $\left(\mathrm{CD}^{+} 698\right.$ cells $/ \mu \mathrm{L}, \mathrm{CD} 4^{+} 181 / \mu \mathrm{L}, \mathrm{CD} 8^{+} 511 / \mu \mathrm{L}, \mathrm{CD} 4 / \mathrm{CD} 8$ ratio 0.35$)$. The patient was treated with 2 courses of pembrolizumab $(2 \mathrm{mg} / \mathrm{kg}$ of body weight, 3-week interval) in addition to continued recurrent administration of IV immunoglobulins $(20 \mathrm{~g}$ every second weeks). One week after the last administration of pembrolizumab, the patient developed a status epilepticus and required temporary intensive care unit treatment. MRI showed progression of PML (figure e-1B and C, links.lww.com/NXI/A153), without evidence of gadolinium-enhancing lesions as a possible indicator of immune reconstitution inflammatory syndrome. JCPyV DNA viral load in CSF increased to 7,685,000 copies/mL. Pembrolizumab treatment was not continued because of the poor general condition of the patient, who died 4 weeks later.

\author{
Correspondence \\ Dr. Grauer \\ oliver.grauer@ukmuenster.de
}

RELATED ARTICLES

\section{Editorial}

Pembrolizumab as

a treatment for PML?:

Waiting for Godot

Page e629

\section{Clinical/Scientific \\ Notes}

Pembrolizumab for progressive multifocal leukoencephalopathy due to primary immunodeficiency

Page e628

\footnotetext{
*These authors contributed equally to this work.

From the Department of Neurology with Institute of Translational Neurology, University of Muenster, Germany.

Go to Neurology.org/NN for full disclosures. Funding information is provided at the end of the article.

The Article Processing Charge was funded by the Open Access Publication Fund WWU.
}

This is an open access article distributed under the terms of the Creative Commons Attribution-NonCommercial-NoDerivatives License 4.0 (CC BY-NC-ND), which permits downloading and sharing the work provided it is properly cited. The work cannot be changed in any way or used commercially without permission from the journal. 
To get further insights into the pathophysiology, we retrospectively performed a detailed immunologic assessment for evaluation of potential treatment effects of pembrolizumab in our and a previously published case (reference case), who was diagnosed for PML and initially evaluated for anti-PD-1 treatment at our clinic. ${ }^{2}$

Polyclonal immune response (figure, A) and PD-1 expression of $\mathrm{CD}^{+}$and $\mathrm{CD} 8^{+}$memory $\mathrm{T}$ cells of both patients were average before pembrolizumab administration (figure, B; T1). After 2 courses of pembrolizumab (T2), PD-1 was downregulated in the presented case (figure B; T2 was not available for the reference case). ${ }^{1} \mathrm{JCPyV}$ VP1-specific $\mathrm{T}$ cells at baseline were present among $\mathrm{CD} 8^{+}$, but very low among $\mathrm{CD}^{+} \mathrm{T}$ cells in the presented case (figure, C). Further analysis showed higher amounts of progenitorexhausted memory $\mathrm{T}$ cells (\% T-cell factor- $1^{+}$of PD$1^{+} \mathrm{CD}_{45 \mathrm{RA}^{-} \text {) in the reference case }}^{2}$ at baseline (figure, $\mathrm{D}$; T1), as well as healthy controls, and a notable increase in terminally exhausted memory $\mathrm{T}$ cells $\left(\% \mathrm{Ki}-67^{+}\right.$of PD- $1^{+}$
$\left.\mathrm{CD} 5 \mathrm{RA}^{-}\right)$in the fatal case after pembrolizumab administration (figure, E). ${ }^{3}$

\section{Discussion}

Very recently, a small case series including 8 patients ${ }^{1}$ with varied underlying causes of immune compromise plus one singular case, ${ }^{2}$ all treated with pembrolizumab, was published and showed heterogeneous results. One possible reason could be the varied underlying causes of immune incompetence including oncologic, viral, and idiopathic entities. In addition, our presented fatal case of PML supports the assumption that a high viral load at diagnosis negatively correlates with PML outcome, ${ }^{4}$ independent of pembrolizumab treatment, but furthermore indicates that pembrolizumab treatment might only be favorable early on. In contrast to an earlier report, decreased PD-1 expression on $\mathrm{T}$ cells after pembrolizumab administration was not indicative of treatment success in the presented case, ${ }^{1}$ neither

Figure Immunologic assessment of pembrolizumab treatment in the presented and reference case

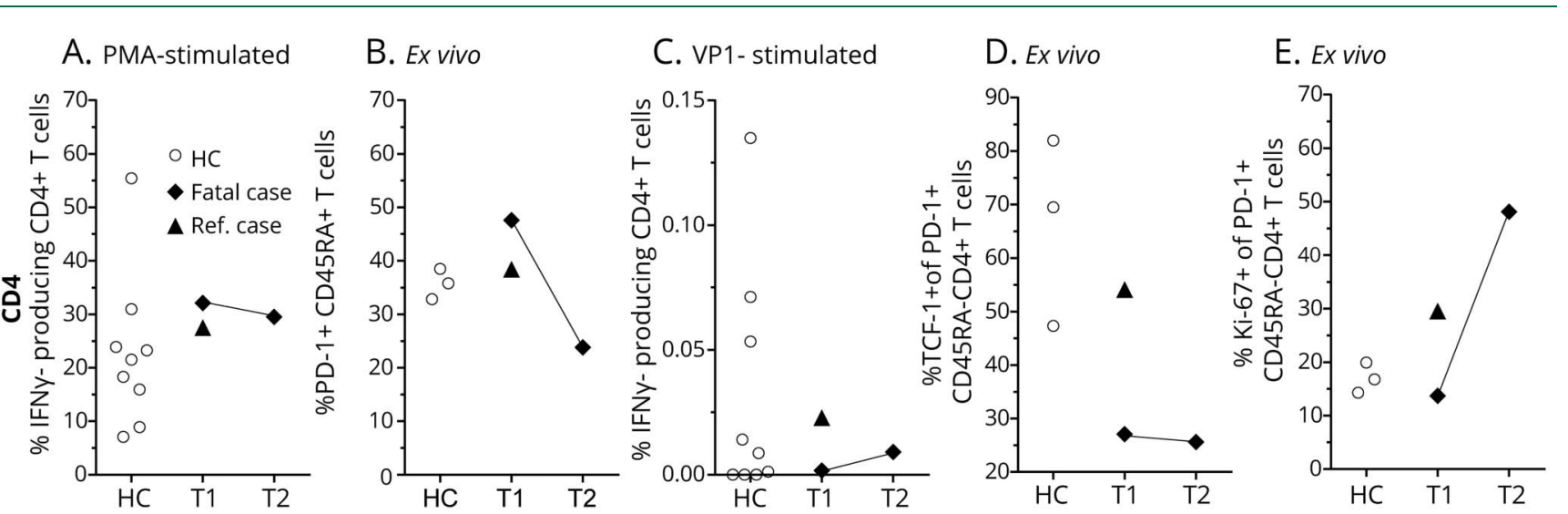

F. PMA-stimulated

G. Ex vivo

H. VP1- stimulated
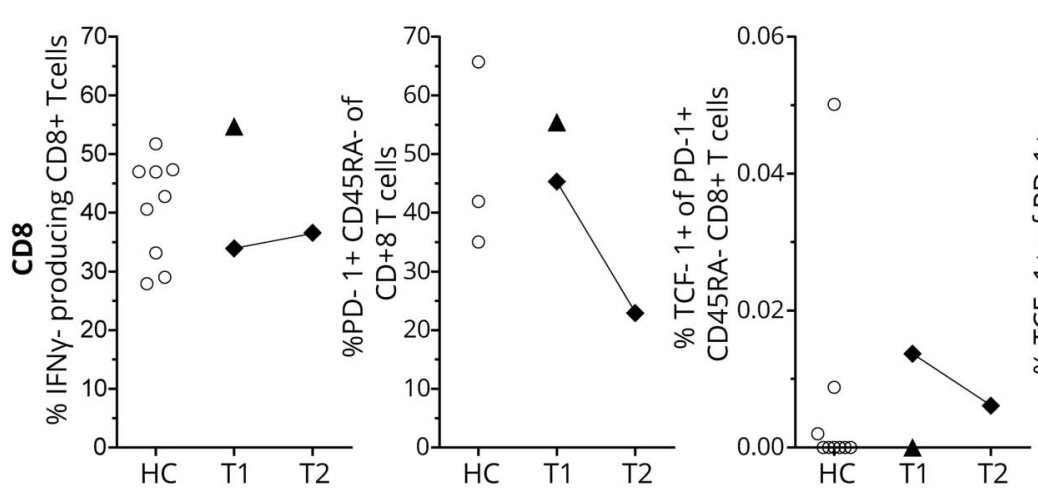

I. Progenitor-exhausted J. Terminally-

$\begin{array}{ll}\text { memory T cells } & \text { exhausted memory } \\ & \text { T cells }\end{array}$

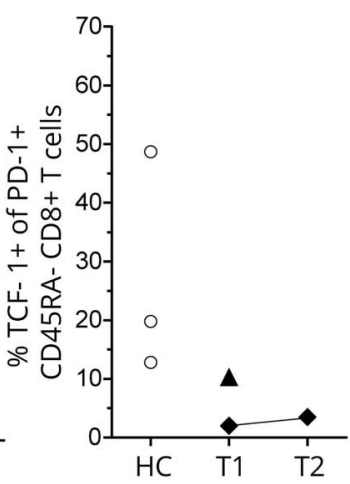

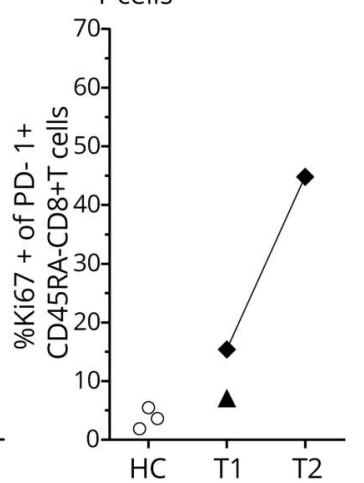

$\mathrm{CD}^{+}$and $\mathrm{CD} 8^{+} \mathrm{T}$ cells were analyzed by flow cytometry after isolation of peripheral blood mononuclear cells (healthy controls $(O), \mathrm{n}=9$, the presented patient $(\bullet)$, and the reference case $(\boldsymbol{\Lambda})$ ). Cytokine production was analyzed after 6 hours of stimulation from PBMC isolated before (T1) and after (T2) pembrolizumab administration. CD4 (A-E) and CD8 (F-J) T-cell IFN-y expression after phorbol-12-myristate 13-acetate/ionomycin/brefeldin A (PMA, A) or JCVyV-VP1 peptide (VP1, C) stimulation is indicated. PD-1 expression of CD45RA ${ }^{-}$memory T cells (B). T-cell factor-1 expression of PD- $1^{+}$CD45RA ${ }^{-}$memory T cells (progenitorexhausted memory T cells, D) and Ki-67 expression of PD-1 ${ }^{+}$CD45RA- memory T cells (terminally exhausted memory T cells, E) are outlined. 
was the amount of JCPyV-specific $\mathrm{CD}^{+} \mathrm{T}$ cells in the compared cases. ${ }^{5}$ However, because the presented, ultimately fatal, case did not elicit a marked $\mathrm{CD} 4^{+} \mathrm{T}$-cell response, whereas the reference case had a detectable $\mathrm{CD} 4^{+}$ T-cell response to viral protein-1 peptide already before pembrolizumab administration, it is tempting to speculate that a CD4 T-cell response is also necessary to sufficiently control JCPyV. ${ }^{6}$ This is corroborated by the HIV field, where the virus-mediated depletion of $\mathrm{CD} 4^{+} \mathrm{T}$ cells can lead to PML in late stages of disease, and JCPyV-specific $\mathrm{CD}^{+}$ $\mathrm{T}$ cells were shown to be critical for PML survival. ${ }^{7}$ Of interest, it was shown very recently that the amount of progenitor-exhausted memory $\mathrm{T}$ cells is associated with prolonged progression-free survival in patients with melanoma receiving anti-PD-1 therapy. ${ }^{3}$ Fitting to this observation, the reference case showed higher amounts of progenitor-exhausted $\mathrm{T}$ cells before pembrolizumab administration, whereas the fatal case presented with a phenotype of terminally exhausted $\mathrm{T}$ cells, in particular at $\mathrm{T} 2$, which were shown to be less responsive to anti-PD1 therapy. ${ }^{3}$

Unfortunately, the clinical decline did not allow treatment continuation, although major adverse events after pembrolizumab administration were not observed. Although we only describe 1 case in detail, the amount of $\mathrm{CD}^{+}$ JCPyV-specific $\mathrm{T}$ cells, progenitor-exhausted memory $\mathrm{T}$ cells, as well as the time point of anti-PD- 1 administration and JCPyV viral load could be promising indicators in future studies to evaluate the efficacy of PML treatment with pembrolizumab.

\section{Study funding}

The authors acknowledge support from the Open Access Publication Fund of the University of Muenster.

\section{Disclosure}

M. Pawlitzki received speaker honoraria from Roche, Genzyme, and Novartis and travel/accommodation/ meeting expenses from Novartis, Biogen, Genzyme, and Merck Serono. T. Schneider-Hohendorf received travel support from Novartis and Biogen. L. Rolfes received travel reimbursements from Merck Serono and Sanofi Genzyme. S.G. Meuth receives honoraria for lecturing and travel expenses for attending meetings from Almirall, Amicus Therapeutics Germany, Bayer Health Care, Biogen, Celgene, Diamed, Genzyme, MedDay Pharmaceuticals, Merck Serono, Novartis, Novo Nordisk, ONO Pharma, Roche, Sanofi Aventis, Chugai Pharma, QuintilesIMS, and Teva. His research is funded by the German Ministry for Education and Research (BMBF), Deutsche Forschungsgemeinschaft (DFG), Else Kröner Fresenius Foundation, German Academic Exchange Service, Hertie Foundation, Interdisciplinary Center for Clinical Studies (IZKF) Muenster, German Foundation Neurology, Almirall, Amicus Therapeutics Germany, Biogen, Diamed, Fresenius Medical Care, Genzyme, Merck Serono,

Novartis, ONO Pharma, Roche, and Teva. H. Wiendl received compensation for serving on scientific advisory boards/steering committees for Bayer Healthcare, Biogen, Sanofi Genzyme, Merck Serono, and Novartis. He has received speaker honoraria and travel support from Bayer Vital GmbH, Bayer Schering AG, Biogen, CSL Behring, EMD Serono, Fresenius Medical Care, Genzyme, Merck Serono, Omniamed, Novartis, and Sanofi Aventis. He has received compensation as a consultant from Biogen, Merck Serono, Novartis, Roche, and Sanofi Genzyme. H. Wiendl also received research support from Bayer Healthcare, Bayer Vital, Biogen, Merck Serono, Novartis, Sanofi Genzyme, Sanofi US and Teva Pharma, Merck Serono, and Novartis. N. Schwab received travel support from Novartis, Biogen, and Genzyme. O.M. Grauer received speaker honoraria and travel/meeting expenses from Roche and MagForce. He received compensation as a consultant from Bristol-Myers Squibb and Gilead Sciences and research support from Bristol-Myers Squibb. Go to Neurology.org/ $\mathrm{NN}$ for full disclosures.

\section{Publication history}

Received by Neurology: Neuroimmunology \& Neuroinflammation July 3, 2019. Accepted in final form August 21, 2019.

\begin{tabular}{|c|c|c|c|}
\hline Name & Location & Role & Contribution \\
\hline $\begin{array}{l}\text { Marc } \\
\text { Pawlitzki, } \\
\text { MD }\end{array}$ & $\begin{array}{l}\text { Department of } \\
\text { Neurology with } \\
\text { Institute for } \\
\text { Translational } \\
\text { Neurology, } \\
\text { University of } \\
\text { Muenster }\end{array}$ & Author & $\begin{array}{l}\text { Study concept and } \\
\text { design, analysis and } \\
\text { interpretation of data, } \\
\text { and critical revision of } \\
\text { the manuscript for } \\
\text { important intellectual } \\
\text { content }\end{array}$ \\
\hline $\begin{array}{l}\text { Tilman } \\
\text { Schneider- } \\
\text { Hohendorf, } \\
\text { PhD }\end{array}$ & $\begin{array}{l}\text { Department of } \\
\text { Neurology with } \\
\text { Institute for } \\
\text { Translational } \\
\text { Neurology, } \\
\text { University of } \\
\text { Muenster }\end{array}$ & Author & $\begin{array}{l}\text { Study concept and } \\
\text { design, analysis and } \\
\text { interpretation of data, } \\
\text { and critical revision of } \\
\text { the manuscript for } \\
\text { important intellectual } \\
\text { content }\end{array}$ \\
\hline $\begin{array}{l}\text { Leoni } \\
\text { Rolfes, MD }\end{array}$ & $\begin{array}{l}\text { Department of } \\
\text { Neurology with } \\
\text { Institute for } \\
\text { Translational } \\
\text { Neurology, } \\
\text { University of } \\
\text { Muenster }\end{array}$ & Author & $\begin{array}{l}\text { Acquisition of data and } \\
\text { analysis and } \\
\text { interpretation of data }\end{array}$ \\
\hline $\begin{array}{l}\text { Sven G. } \\
\text { Meuth, MD, } \\
\text { PhD }\end{array}$ & $\begin{array}{l}\text { Department of } \\
\text { Neurology with } \\
\text { Institute for } \\
\text { Translational } \\
\text { Neurology, } \\
\text { University of } \\
\text { Muenster }\end{array}$ & Author & $\begin{array}{l}\text { Study concept and } \\
\text { design and critical } \\
\text { revision of the } \\
\text { manuscript for } \\
\text { intellectual content }\end{array}$ \\
\hline $\begin{array}{l}\text { Heinz } \\
\text { Wiendl, MD }\end{array}$ & $\begin{array}{l}\text { Department of } \\
\text { Neurology with } \\
\text { Institute for } \\
\text { Translational } \\
\text { Neurology, } \\
\text { University of } \\
\text { Muenster }\end{array}$ & Author & $\begin{array}{l}\text { Study concept and } \\
\text { design and critical } \\
\text { revision of the } \\
\text { manuscript for } \\
\text { important intellectual } \\
\text { content }\end{array}$ \\
\hline
\end{tabular}


Appendix (continued)

\begin{tabular}{|c|c|c|c|}
\hline Name & Location & Role & Contribution \\
\hline $\begin{array}{l}\text { Nicholas } \\
\text { Schwab, } \\
\text { MD }\end{array}$ & $\begin{array}{l}\text { Department of } \\
\text { Neurology with } \\
\text { Institute for } \\
\text { Translational } \\
\text { Neurology, } \\
\text { University of } \\
\text { Muenster }\end{array}$ & Author & $\begin{array}{l}\text { Study concept and } \\
\text { design, analysis and } \\
\text { interpretation of data, } \\
\text { and critical revision of } \\
\text { the manuscript for } \\
\text { important intellectual } \\
\text { content }\end{array}$ \\
\hline $\begin{array}{l}\text { Oliver M. } \\
\text { Grauer, MD, } \\
\text { PhD }\end{array}$ & $\begin{array}{l}\text { Department of } \\
\text { Neurology with } \\
\text { Institute for } \\
\text { Translational } \\
\text { Neurology, } \\
\text { University of } \\
\text { Muenster }\end{array}$ & Author & $\begin{array}{l}\text { Study concept and } \\
\text { design, analysis and } \\
\text { interpretation of data, } \\
\text { drafting the } \\
\text { manuscript, and } \\
\text { critical revision of the } \\
\text { manuscript for } \\
\text { important intellectual } \\
\text { content }\end{array}$ \\
\hline
\end{tabular}

\section{References}

1. Cortese I, Muranski P, Enose-Akahata Y, et al. Pembrolizumab treatment for progressive multifocal leukoencephalopathy. New Engl J Med 2019;380: $1597-1605$

2. Rauer S, Marks R, Urbach H, et al. Treatment of progressive multifocal leukoencephalopathy with pembrolizumab. N Engl J Med 2019;380:1676-1677.

3. Miller BC, Sen DR, Al Abosy R, et al. Subsets of exhausted CD8+ T cells differentially mediate tumor control and respond to checkpoint blockade. Nat Immunol 2019;20: 326-336.

4. Blankenbach K, Schwab N, Hofner B, Adams O, Keller-Stanislawski B, Warnke C. Natalizumab-associated progressive multifocal leukoencephalopathy in Germany. Neurology 2019;92:e2232-e2239.

5. Koralnik IJ. Can immune checkpoint inhibitors keep JC virus in check? N Engl J Med 2019;380:1667-1668.

6. Yousef S, Planas R, Chakroun K, et al. TCR bias and HLA cross-restriction are strategies of human brain-infiltrating JC virus-specific CD4+ $\mathrm{T}$ cells during viral infection. J Immunol 2012;189:3618-3630.

7. Gasnault J, Kahraman M, Goër Herve MGde, Durali D, Delfraissy JF, Taoufik Y. Critical role of JC virus-specific CD4 T-cell responses in preventing progressive multifocal leukoencephalopathy. AIDS 2003;17:1443-1449. 


\title{
Neurology \\ Neuroimmunology \& Neuroinflammation
}

\author{
Ineffective treatment of PML with pembrolizumab: Exhausted memory T-cell subsets \\ as a clue? \\ Marc Pawlitzki, Tilman Schneider-Hohendorf, Leoni Rolfes, et al. \\ Neurol Neuroimmunol Neuroinflamm 2019;6;e627 \\ DOI 10.1212/NXI.0000000000000627
}

This information is current as of October 9, 2019

Updated Information \&

Services

References

Citations

Subspecialty Collections

Permissions \& Licensing

Reprints including high resolution figures, can be found at:

http://nn.neurology.org/content/6/6/e627.full.html

This article cites 7 articles, 1 of which you can access for free at: http://nn.neurology.org/content/6/6/e627.full.html\#\#ref-list-1

This article has been cited by 5 HighWire-hosted articles: http://nn.neurology.org/content/6/6/e627.full.html\#\#otherarticles

This article, along with others on similar topics, appears in the following collection(s):

Autoimmune diseases

http://nn.neurology.org//cgi/collection/autoimmune_diseases

Viral infections

http://nn.neurology.org//cgi/collection/viral_infections

Information about reproducing this article in parts (figures,tables) or in its entirety can be found online at:

http://nn.neurology.org/misc/about.xhtml\#permissions

Information about ordering reprints can be found online:

http://nn.neurology.org/misc/addir.xhtml\#reprintsus

Neurol Neuroimmunol Neuroinflamm is an official journal of the American Academy of Neurology.

Published since April 2014, it is an open-access, online-only, continuous publication journal. Copyright

Copyright $\left({ }^{\circ} 2019\right.$ The Author(s). Published by Wolters Kluwer Health, Inc. on behalf of the American

Academy of Neurology.. All rights reserved. Online ISSN: 2332-7812.

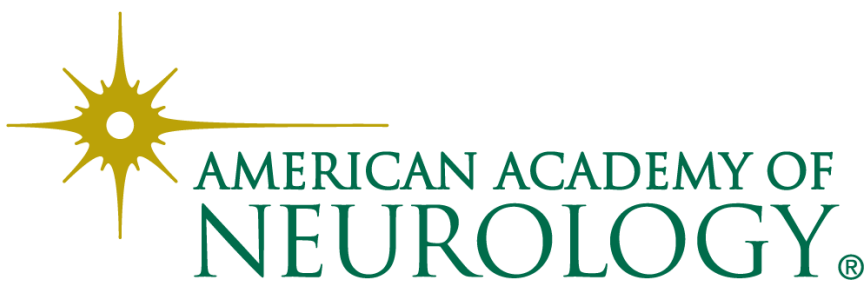

